\title{
Are Students Ethical Human Business Communicative Agents? Analysis Between A Six Year Period
}

\author{
S.M. Fredricks \\ Penn State Brandywine
}

The growth in graduates indicates that those professionals are now shaping the ethical climate of our society (Birtch, Chiang, \& T, 2014). Ten scenarios were created to test students' ability to act as ethical human communicative agents (Ballard et al., 2014). Data was collected from undergraduates, 2009 and then in 2016, in various degree programs and geographic locations in the United States, but predominately a Northeastern university. Two scenarios illustrated significance differences. This does not necessarily indicate less or more ethical behavior, but it does illustrate a difference between participants. Additional indications for business communication ethics literacy will be discussed.

\section{INTRODUCTION}

"Right is right, and wrong is wrong, and a body ain't got no business doing wrong when he ain't ignorant and knows better." - Mark Twain, The Adventures of Huckleberry Finn ("Ethics Quotes (1081 quotes)," n.d.)

As Mark Twain suggests, we should know the difference between right and wrong. But every day brings us new tasks, duties and responses to our surrounding environment, and we are constantly being asked to make ethical choices, whether to go through a yellow light or take the post-it notes home from work (Shockley-Zalabak, 2011). And we also know that overall, "Questions of right and wrong arise whenever people communicate" NCA Credo (Andersen, 2000). So, if we are constantly communicating, we are constantly facing ethical rights or wrongs However, what causes our actions to be one or the other? How do we become communications ethics literate, "..the sorting out and discernment of the goods that we protect and promote (Arnett, Fritz, and Bell 2009, p. 5)?" And more so, how do we act as, an ethical human communication agent?

It is education, and it is teachable (Arnett et al., 2009). To learn about ethics and grow we need to participate in the educational process. Education, by its definition, involves learning and gaining knowledge ("Higher Education | Definition of Higher education by Merriam-Webster," n.d.) and ethics education narrows that focus to gaining knowledge, literacy, about ethics (Arnett et al., 2009).

Ethics education takes on many forms and through many means. There are courses, assignments, training sessions, institutes, and even degrees centered on ethics, morality, and theoretical practices. The influences and effectiveness of these endeavors has been called into question over and over again (Birtch et al., 2014; Cheng, 2015; Dzuranin, Shortridge, \& Smith, 2013; Holland \& Albrecht, 2013; Lau \& L, 2010; Petrick, Cragg, \& Sañudo, 2011; Yanikkaya, 2015). This article is designed to review if there was 
an overall change in students' potential ethical choices, an improvement in their communication ethics literacy, over a six-year period. It was hypothesized that current students would select more ethical choices than previous students because of the reinforced emphasis on ethics education throughout their educational experience.

\section{REVIEW OF LITERATURE}

Over the past decade, business ethical dilemmas have blanketed our society (See Figure 2). The growth in graduates indicates that those professionals are now shaping the ethical climate and social norms of our society (Birtch et al., 2014). Candace deRussy (2003) believes that higher education is the place for students to learn about ethics. Essentially; "The professoriate is a gatekeeper, determining a student's first exposure to ethical standards, traditions, and the responsibilities of peer evaluation (de Russy, 2003, p. 1)." A 2009 study indicated that 73\% of employers are; "Expecting students to work through ethical issues and debates to form their own judgments about the issues at stake (Hart Research Associates, 2010, p. 8)." There is great emphasis on higher education institutions creating ethical human communicative agents; those individuals who are able to "understand [sic] the role of communication ethics in how we make decision and engage in the world around us (Ballard et al., 2014, p.66)." The following paragraphs touch on the definition of ethical communicative agent through communication ethics, followed by literature regarding different calls for ethics education, models of that education, and previous analysis of these scenarios.

\section{Ethical Human Communicative Agent}

To fully comprehend what an ethical human communication agent is, we must first define communication ethics which will lead us to communication literacy and then to the ethical human communicative agent. Communication ethics involves applying ethics to circumstances that involve communication, specifically human communication (Neher \& Sandin, 2007). Communication ethics encompasses those "beyond our own immediate lives and relationships (Neher \& Sandin, 2007, p.9)." To conduct communication ethics research means to test the tension between theoretical versus applied. "On the one hand, it questions ethical theories....... On the other, it investigates past ethical dilemmas to offer prescriptions for future ethical choices (Ballard, Ortiz, \& McManus, 2016, p. 158)." This tension, or rather dialogue, leads to the pragmatic theory of communication ethics literacy which "identifies the good in the interplay of self and Other and the particular historical moment attending to what is protected and promoted (Arnett et al., 2009, p. 210)." In this era of differences, it has become more of a necessity to learn communication ethics literacy (Holba, 2013).

The interplay of self and Other engages us in a learning experience and it causes a reflection of our own behavior and actions. The ability to learn, practice communication ethics literacy, and understand how our actions may impact others defines an ethical human communication agent. As Ballard et al (2014) explain, “... understanding the role of communication ethics in how we make decisions and engage in the world around us is essential in order to unpack, discover, and understand what it means to engage as ethical human communicative agents (Ballard et al., 2014, p. 66)." Thus, this research explores whether students are able to develop such skills and engage in such ethical actions.

\section{Call for Ethics Education}

Early analysis of corporations indicated that changes in financial influences are also affecting corporate social responsibility and the need for additional business ethics education (Ryan, 2005). Furthermore, with the financial crisis and additional issues that are influenced by North American theories of economics and capitalism, there has been a call for more ethics education of professionals including those both inside outside of the business discipline (Petrick et al., 2011).

A multidisciplinary call for ethics education has swept higher education. Integrating Communication Ethics into other disciplines including engineering, science, and business are just a few (Canary et al., 2014). The call by the Advanced Collegiate Schools of Business (AACSB) and the European Quality 
Improvement Systems (EQUIS) accrediting body has also signaled an influence on ethics within business programs (Cheng, 2015; Floyd, Xu, Atkins, \& Caldwell, 2013; Martinov-bennie \& Mladenovic, 2015). Furthermore, the Association of American Colleges and Universities (AAC \& U) 2013 survey of employers indicated that ethics was at a high to very important level (Ballard et al., 2014). This is further delineated to various programs, besides business, to accounting (Anonymous, 2005; Dellaportas, Jackling, Leung, \& Cooper, 2011; Dosch \& Wambsganss, 2006; Fulmore, 2015; Mastracchio, JiménezAngueira, \& Toth, 2015), nursing (Choe, Song, \& Kang, 2013), psychiatry (Christensen \& Tueth, 1998), and even physical therapy (Delany, Edwards, Jensen, Skinner, \& Geddes, 2010).

\section{Models of Ethics Education}

Various models of ethics education have become more familiar throughout higher education. Attempts were made and continue to be made to incorporate ethics training into the classroom setting ((e.g. Basic Business Communication -(Golen, Powers, \& Titkemeyer, 1985) and Arizona State University Intercultural Communication class - (Bower \& Society for Ethics Across the Curriculum, 2011)). There is interest in teaching ethics through online classes as well (Cheng, 2015). A 2015 study indicated that there has been a $51 \%$ increase over the past nineteen years of the required or optional communication ethics courses (Swenson-Lepper et al., 2015). However, the format of such courses deal less with the theoretical approaches and more with the professional approaches to ethics; geared more towards employment and application (Swenson-Lepper et al., 2015). Some higher education institutions are taking it a step further, beyond the classroom, and incorporating ethics into their departments' mission ((e.g. Duquesne University Department of Communication and Rhetorical Studies -("Communication \& Rhetorical Studies," n.d.)). Still, others are creating centers to encourage ethics across curriculum ((e.g. Illinois Institute of Technology - (Davis, Hildt, \& Laas, n.d.) and Northern Illinois University College of Business - (Dzuranin et al., 2013)).

Overall, there seems to be a mix between effectiveness (Lau \& L, 2010) and disappointment of ethics education (Sigurjonsson, Arnardottir, Vaiman, \& Rikhardsson, 2015). There are many challenges and issues affecting the future of these educational programs including working within multidiscipline and professionalization (Petrick et al., 2011), globalization and quality of ethics research (Holland \& Albrecht, 2013), to name a few. Some researchers indicated that they were disappointed by students who seem to graduate with a lack of ethics which indicates a stronger need to work with industries and school (Sigurjonsson et al., 2015).

\section{Previous Scenario Analysis}

The initial data from these scenarios indicated differences for kinship (Fredricks, Ramsey, and Hornett, 2010; Tilley, Fredricks, and Hornett, 2012), geographical location (U.S.A., New Zealand, Czech Republic, and Russia)(Fredricks and Tilley, 2014; Fredricks, Tilley, and Pauknerová, 2014; Schmidt and Uecker, 2015), employment status (Fredricks, 2015), and gender (Fredricks et al., 2014).

\section{METHODOLOGY}

The initial investigation of how students communicate about their behavioral choices for particular ethical dilemmas developed into scenarios. Ten scenarios were created from these situations, class discussions, and personal experiences. These scenarios focused on the following ethical dilemmas; theft, familial influence on decisions, illegal activities, personal gain, and personal relationships (see Figure 2). Data was collected from undergraduates in various degree programs and geographic locations in the United States, but predominately a northeastern university. These scenarios were than redistributed to undergraduate students within the past two years, six years after the initial collection, to test for any significance differences between the years. For both years, these students had the option to take an ethics course, but it was not required for their degree. Most respondents learned about ethics in a variety of courses and a variety of means. 
All data was collected from the students, coded, and inputted into SPSS. Analysis and calculations were conducted through SPSS where basic frequencies were calculated for all ten scenarios. To test for significance between the 2009 and 2016 years, a Chi-Square with the Pearson Correlation Coefficient was used (Babbie, 1998).

\section{Limitations}

The use of scenarios, often referred to as vignettes, was chosen because this methods "helps standardize the social stimulus across respondents"(Alexander \& Becker, 1978). While surveys can be strong on reliability, they can be weak in validity and artificial in testing (Babbie, 1998). Since the survey questions are experientially based but artificial, how participants respond does not necessarily mean that they will take that particular action in real life. However, the strength of the survey approach is the reliability of asking the same standard questions of all the participants for both years.

\section{RESULTS}

Percentages of frequencies for $2009(\mathrm{~N}=454)$ and $2016(\mathrm{~N}=71)$ by each year within each scenario are depicted in Figures 3 through 12. Significant difference, with a Chi Square $>.05$, was indicated for only two scenarios. This specifies that for eight of the ten scenarios, the respondents selected similar choices. Scenario VII, about selling a watch, and Scenario VIII, about dating a co-worker, had significant differences between the years with their choices (see Figure 9 and Figure 10).

Scenario I, regarding checking out at a grocery store, and Scenario II, regarding kinship and checking out, showed no significant differences, (see Figure 3 and Figure 4), but the change in responses when the uncle was introduced in the scenario - Scenario I to Scenario II - increased the action level. The do "Nothing" response in the first scenario $(2009, \mathrm{n}=157,34.8 \% ; 2016, \mathrm{n}=29,40.8 \%)$ was the second highest choice, but fell to three or four in the second scenario $(2009, \mathrm{n}=15,3.4 \% ; 2016, \mathrm{n}=5,7.5 \%)$.

As well, Scenario IX did not show significance but did illustrate differences between the two years with their third and fourth choices (See Figure 11). The 2016 respondents wanted to do "Nothing" as their second choice when encountering a dilemma of stealing by their supervisor $(n=14,19.4 \%)$. The 2009 respondents, on the other hand, chose to do "Nothing" as their third choice $(\mathrm{n}=52,11.5 \%)$

In addition, although not indicating significance, seven of the ten scenarios showed nuances between the two years. A higher percentage of the 2016 respondents would choose to do an ethical action over the same choice for the 2009 respondents; Scenario II - "Speak to the man", Scenario III - "Talk to Your boss", Scenario IV - "Speak to your boss", Scenario VI - "Confront the employee", Scenario VII - "Try and steer them towards a less expensive watch", Scenario VIII - "Tell the person..", and Scenario X "Tell my direct supervisor."

\section{DISCUSSION}

Overall, there was minimal, but noticeable, change between the 2009 and 2016 respondents' choices for the ten scenarios. Two scenarios showed significant differences. While the other eight scenarios did not show significant differences, they do illustrate nuances between the years. These nuances may be due, in part, to the heightened demand for more ethical human communicative agents. Scenario VII \& VIII showed significant differences. Regarding selling the watch in Scenario VII; more 2016 students preferred to steer them away from the expensive watch and not sell them the watch. Students were looking out for the best interest of the consumer. Regarding dating a co-worker in Scenario VIII; 2016 students would not get involved versus those of 2009 which would ask the person out. Though the initial data collection was prior to the Bill Crosby trial, \#MeToo and \#TimesUp, there may be more emphasis on minimizing workplace interpersonal relationships. Although not conclusive, the reflective process in communication ethics literacy may have helped the students with their decisions.

Additional nuisances became evident but were not significant for a number of the scenarios. Scenario I illustrated that the 2016 respondents were less willing to speak to the man about the chicken and more 
willing to do nothing than those of 2009 , which seemingly indicates less ethical actions. However, when you add the component of kinship (Tilley et al., 2012) such as Scenario II, the 2016 respondents are more likely to speak to the man than 2009. However, the 2016 respondents are still more likely to do nothing than the 2009 respondents. Scenario III finds the respondents similar in their choices but the frequency percentages indicate that 2016 are more willing to talk to their boss and less likely to proceed to the trading floor. Scenario IV finds the 2016 respondents more willing to speak to their boss than the Chief Ethics Officer than the 2009 respondents. Scenario IV illustrates that both years are willing to confront the employee but more 2016 were willing to do so. Some of the responses were tied, equal number of responses, between pretending not to know and adjust the bill while 2009 respondents had a higher frequency to adjust the client bill. This indicates that there is a shift in communicative ethical behaviors, leaning more towards an ethical action. It could be surmised that 2016 students are perhaps more ethically oriented, with more communicative reflection upon the good, than previous students which correlates to Lau's research (Lau \& L, 2010).

\section{Limitations and Future Research}

Certain limitations became obvious while conducting this research that leads directly to future research endeavors. This study does not include a "peer pressure" or element of "expectation answering" where the respondents choose their answers based upon how they believe it should be answered while not answering it as themselves. This has been identified as a weakness of this methodology (Babbie, 1998) but could lead to further investigation.

In addition, the difference in the number of respondents; $2009(\mathrm{~N}=454)$ and $2016(\mathrm{~N}=71)$, between the years could lean the data one way or another. This was minimized by using frequency percentages within each scenario. Chi-Square was also used when looking for significance, such as in Scenario VII and VIII.

The research didn't ask respondents about their ethics education (e.g. courses, assignments...) and as identified for many respondents, it was simply a topic covered in class. As Yanikkaya (2015) states; "....students in the example cases have become to treat higher education only as a means to reach one goal, which is in brief, to find a job (Yanikkaya, 2015, p. 532)." So education and answering the scenarios are just a means to an end. Further evaluation of this issue could lead to more research on the effectiveness of the ethics education.

It is not a question of being more communication ethic literate or acting more ethical; it is more of the which position on the ethics continuum scale people act ethically (Boylan, 2001). So, our reflection of the Other can be places on a continuum, the same with good versus evil. This might be able to position communication ethics literacy on a multidimensional continuum with further development and exploration.

\section{CONCLUSION}

Undergraduate students from both years as varying degrees are illustrating their communication ethics literacy by selecting more ethical choices. Students from more recent years may be more aware and maybe more empathic of financial constraints on consumers and are more aware now of work place interpersonal relationship issues. As always, ethics literacy should be incorporated into all levels of education. Enhancing the course work and even requiring courses could make a more significant impact on our graduates.

\section{ACKNOWLEDGEMENT}

Special thanks to the following student for his assistance in the initial research: Fitzpatrick Owen, Undergraduate Student, graduated, Penn State Brandywine.

This paper was presented at the $15^{\text {th }}$ National Communication Ethics Conference, June 2018. 


\section{REFERENCES}

Alexander, C. S., \& Becker, H. J. (1978). The Use of Vignettes in Survey Research. Public Opinion Quarterly, 42(1), 93.

Andersen, K. E. (2000). Developments in Communication Ethics: The Ethics Commission. JACA ANNANDALE-, 131-144.

Anonymous. (2005). A Call to the Classroom: More Ethics Courses. CPA Practice Management Forum; Riverwoods, 1(9), 3,18+.

Arnett, R. C., Fritz, J. M. H., \& Bell, L. M. (2009). Communication ethics literacy: dialogue and difference. Los Angeles: Sage Publications.

Babbie, E. R. (1998). The Practice of Social Research. Belmont, Calif.: Wadsworth Pub. Co.

Ballard, R. L., Bell McManus, L. M., Holba, A. M., Jovanovic, S., Tompkins, P. S., Charron, L. J. N., ... Swenson-Lepper, T. (2014). Teaching Communication Ethics as Central to the Discipline. Journal of the Association for Communication Administration, 33(2), 65-83.

Ballard, R. L., Ortiz, M. V., \& McManus, L. M. B. (2016). Communication Ethics: A Vital Resource in an Ever-Changing World. Choice; Middletown, 54(2), 155-158,160-164.

Birtch, T. A., Chiang, F. F., \& T. (2014). The Influence of Business School's Ethical Climate on Students' Unethical Behavior. Journal of Business Ethics, 123(2), 283-294. http://dx.doi.org/10.1007/s10551-013-1795-y

Bower, C.-L., \& Society for Ethics Across the Curriculum. (2011). Integrating Ethical Learning Into Intercultural Communication Classes: Teaching Ethics, 11(2), 57-61. https://doi.org/10.5840/tej20111127

Boylan, M. (2001). Business Ethics. Retrieved from http://slideplayer.com/slide/2573883/9/images/7/The+Ethical+Continuum+Low+High+FIGURE $+2 \%$ E2\%80\%932.jpg

Canary, H. E., Taylor, J. L., Herkert, J. R., Ellison, K., Wetmore, J. M., \& Tarin, C. A. (2014). Engaging Students in Integrated Ethics Education: A Communication in the Disciplines Study of Pedagogy and Students' Roles in Society. Communication Education, 63(2), 83-104. https://doi.org/10.1080/03634523.2014.888457

Cheng, P. (2015). University Lecturers' Intention to Teach an Ethics Course: A Test of Competing Models. Journal of Business Ethics, 126(2), 247-258. http://dx.doi.org/10.1007/s10551-0131949-y

Choe, K., Song, E., \& Kang, Y. (2013). Recognizing bioethical issues and ethical qualification in nursing students and faculty in South Korea. Nursing Ethics; London, 20(2), 213-225. http://dx.doi.org.ezaccess.libraries.psu.edu/10.1177/0969733012472734

Christensen, R. C., \& Tueth, M. J. (1998). Pharmaceutical companies and academic departments of psychiatry: A call for ethics education. Academic Psychiatry; New York, 22(2), 135.

Communication \& Rhetorical Studies (n.d.). Retrieved June 26, 2018, from $\mathrm{http} / / /$ www.duq.edu/academics/schools/liberal-arts/academic-programs/communication-andrhetorical-studies

Davis, M., Hildt, E., \& Laas, K. (n.d.). Twenty-Five Years of Ethics Across the Curriculum: An Assessment. Teaching Ethics, 16(1), 55-74.

de Russy, C. D. (2003, September 19). Professional Ethics Begin on the College Campus. The Chronicle of Higher Education. Retrieved from https://www.chronicle.com/article/Professional-EthicsBegin-on/17511

Delany, C. M., Edwards, I., Jensen, G. M., Skinner, E., \& Geddes, E. L. (2010). Closing the Gap Between Ethics Knowledge and Practice Through Active Engagement: An Applied Model of Physical Therapy Ethics/Invited Commentary/Author Response. Physical Therapy; Washington, 90(7), $1068-1078$.

Dellaportas, S., Jackling, B., Leung, P., \& Cooper, B. J. (2011). Developing an Ethics Education Framework for Accounting. Journal of Business Ethics Education; Edinburgh, 8, 63-82. 
Dosch, R. J., \& Wambsganss, J. R. (2006). The Blame Game: Accounting Education Is Not Alone. Journal of Education for Business; Washington, 81(5), 250-254.

Dzuranin, A. C., Shortridge, R. T., \& Smith, P. A. (2013). Building Ethical Leaders: A Way to Integrate and Assess Ethics Education. Journal of Business Ethics, 115(1), 101-114. http://dx.doi.org/10.1007/s10551-012-1371-x

Ethics Quotes (1081 quotes). (n.d.). Retrieved May 18, 2018, from https://www.goodreads.com/quotes/tag/ethics?page=2

Floyd, L. A., Xu, F., Atkins, R., \& Caldwell, C. (2013). Ethical Outcomes and Business Ethics: Toward Improving Business Ethics Education. Journal of Business Ethics, 117(4), 753-776. http://dx.doi.org/10.1007/s10551-013-1717-z

Fredricks, S. M. (2015). The Impact of Employment Status and Geographic Location; United States, New Zealand, and Czech Republic, on Ethical Choices for Three Business Scenarios. International Journal of Business and Social Science, 6(6), 17.

Fredricks, S. M., \& Tilley, E. (2014). Confluence of the Power-Distance Cultural Dimensions between the United States, New Zealand, and Germany in Ethical Responses. International Journal of Humanities and Social Science, 4(4), 14.

Fredricks, S. M., Tilley, E., \& Pauknerová, D. (2014). Limited gender differences in ethical decision making between demographics in the USA and New Zealand. Gender in Management; Bradford, 29(3), 126-147. http://dx.doi.org.ezaccess.libraries.psu.edu/10.1108/GM-08-2012-0069

Fredricks, S., Ramsey, M., \& Hornett, A. (2010). Kinship and Bystander Effect: The Role of Others in Ethical Decisions. Journal of Religion and Business Ethics, 2(1), 23.

Fulmore, A. L. (2015). Effect of a Business Ethics Course on the Moral Reasoning of Undergraduate Accounting Students (D.B.A., Northcentral University). Retrieved from https://search-proquestcom.ezaccess.libraries.psu.edu/docview/1746623314/abstract/1F04356ED2274012PQ/3

Golen, S., Powers, C., \& Titkemeyer, M. A. (1985). How to Teach Ethics in a Basic Business Communication Class--Committee Report of the 1983 Teaching Methodology and Concepts Committee, Subcommittee 1. Journal of Business Communication, 22(1), 75-83.

Hart Research Associates. (2010). Raising The Bar: Employers' Views On College Learning In The Wake of The Economic Downturn (p. 10) [A Survey Among Employers Conducted on Behalf of the AAC \& U]. The Association of American Colleges and Universities.

Higher Education | Definition of Higher education by Merriam-Webster. (n.d.). Retrieved March 22, 2016, from http://www.merriam-webster.com/dictionary/higher\%20education

Holba, A. (2013). Arnett, R. C., Fritz, J. H., Bell, L. M.: Communication Ethics Literacy: Dialogue and Difference. Journal of Business Ethics: JBE; Dordrecht, 112(3), 545-548. http://dx.doi.org.ezaccess.libraries.psu.edu/10.1007/s10551-012-1586-x

Holland, D., \& Albrecht, C. (2013). The Worldwide Academic Field of Business Ethics: Scholars' Perceptions of the Most Important Issues. Journal of Business Ethics, 117(4), 777-788. http://dx.doi.org/10.1007/s10551-013-1718-y

Lau, C. L., \& L. (2010). A Step Forward: Ethics Education Matters! Journal of Business Ethics, 92(4), 565-584. http://dx.doi.org/10.1007/s10551-009-0173-2

Martinov-bennie, N., \& Mladenovic, R. (2015). Investigation of the Impact of an Ethical Framework and an Integrated Ethics Education on Accounting Students' Ethical Sensitivity and Judgment. Journal of Business Ethics, 127(1), 189-203. http://dx.doi.org/10.1007/s10551-013-2007-5

Mastracchio, N. J., Jiménez-Angueira, C., \& Toth, I. (2015). The State of Ethics in Business and the Accounting Profession. The CPA Journal; New York, 85(3), 48-52.

Neher, W., \& Sandin, P. (2007). Communicating Ethically: Character, Duties, Consequences, and Relationships. Taylor \& Francis.

Petrick, J. A., Cragg, W., \& Sañudo, M. (2011). Business Ethics in North America: Trends and Challenges. Journal of Business Ethics, 104, 51-62. http://dx.doi.org/10.1007/s10551-012-12621

36 Journal of Leadership, Accountability and Ethics Vol. 16(2) 2019 
Ryan, L. V. (2005). Corporate Governance and Business Ethics in North America: The State of the Art. Business and Society; Chicago, 44(1), 40-73.

Schmidt, J. J., \& Uecker, D. C. (2015). Business Ethics in the United States and Russia. Journal of Leadership, Accountability and Ethics, 12(2), 92-102.

Shockley-Zalabak, P. (2011). A Matter of Trust. Communication World, 28(3), 16-21.

Sigurjonsson, T. O., Arnardottir, A. A., Vaiman, V., \& Rikhardsson, P. (2015). Managers' Views on Ethics Education in Business Schools: An Empirical Study. Journal of Business Ethics, 130(1), 1-13. http://dx.doi.org/10.1007/s10551-014-2202-z

Swenson-Lepper, T., Leavitt, M. A., Hoffer, M., Charron, L. N., Ballard, R. L., Bell McManus, L. M., ... Tompkins, P. S. (2015). Communication Ethics in the Communication Curriculum: United States, Canada, and Puerto Rico. Communication Education, 64(4), 472-490. https://doi.org/10.1080/03634523.2015.1041996

Tilley, E. N., Fredricks, S. M., \& Hornett, A. (2012). Kinship, culture and ethics in organisations. Journal of Communication Management; London, 16(2), 162-184.

http://dx.doi.org.ezaccess.libraries.psu.edu/10.1108/13632541211217588

Yanikkaya, B. (2015). A Discussion on Teaching \& Ethics And Teaching Communication Ethics in the Digital Age. Dijital Çă̆da Öğretim \& Etik ve İletişim Etiği Öğretimi Üzerine Bir Tartışma., 6(11), 532-553. 


\section{APPENDIX}

FIGURE 1

TIMELINE OF ETHICS INCIDENTS
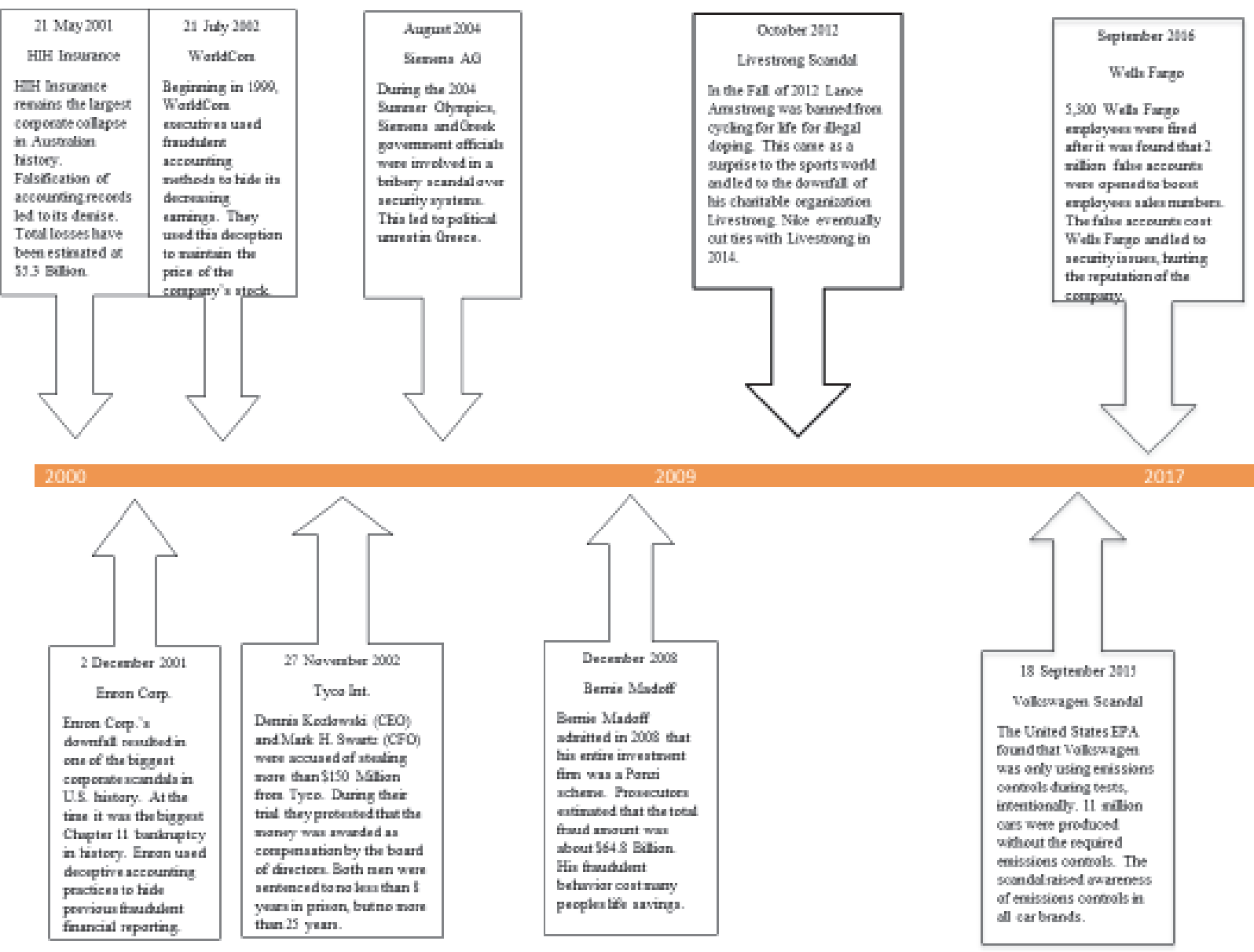

38 Journal of Leadership, Accountability and Ethics Vol. 16(2) 2019 


\section{FIGURE 2}

\section{TEN SCENARIOS}

Below are ten scenarios. There is no right or wrong answer. Please review each scenario and pick the answer most closely related to what you would do. You will have 15-20 minutes to complete this survey.

Scenario I:

Please check the box that best answers your decision. Thank you.

You are shopping at the local supermarket and are second in line at the checkout. The man in front of you has emptied his cart on the conveyor belt. You start to empty your cart and notice that he has a large package of chicken down below on the bottom rung of the cart. It is hidden from the cashier's view. The cashier does not notice. What do you do?

\section{Nothing}

Speak to the man

Speak to the cashier

Other (please explain):

Scenario II:

You are shopping at the local supermarket and are second in line at the check out. The man in front of you has emptied his cart on the conveyor belt. You start to empty your cart and notice that he has a large package of chicken down below on the bottom rung of the cart. It is hidden from the cashier's view. The cashier does not notice.

Your closest relative is the manager of the meat department in this store and personally pays for inventory shortages. What do you do?

Nothing

Speak to the man

Speak to the cashier

Other (please explain):

Scenario III:

You are working for a major corporation in your home town. The pay is good and the benefits are what you classify as exceptional. As part of your benefits, your retirement provides for stock options. In fact, the basis of your retirement is company stock options. The company seems to be doing well and the stock price is rising. You feel on top of the world, your stock price is increasing and you are getting an increasing share of a rising stock. Your job is flexible and is providing significant opportunities for you. You are sitting at your desk when you get a phone call from your boss, asking for your assistance. The Security and Exchange Commission is conducting a spot check on your company and its trading behaviors. The phones on the trading floor need to be covered by personnel. It is well known throughout the company that these phones are not staffed because there is no trading activity. Your boss encourages you to drop everything and to proceed to the trading floor in order "to put on a good show" for the S.E.C. What do you do?

$\square$ Nothing, ignore the request and continue with your work

$\square$ Talk to your boss about the request

Proceed to the trading floor as directed

Tell one of your friends at work and you both agree to stay behind.

$\square$ Tell one of your friends at work and convince your friend to go with you to the trading floor 


\section{Scenario IV:}

Assume that you proceed to the trading floor no questions asked because your boss requested it.

As you proceed up to the trading floor, you notice several more employees making their way there as well. As you enter the trading floor, you are given instructions to find a desk and pick up the phone and pretend to place calls to people from an established list. You watch more and more company employees enter the floor and realize that there are over seventy (70) employees relocated to the trading floor. As you find a desk, and start placing calls, members of the S.E.C. staff arrive and are given a tour of the floor. Once they have gone, further instructions are given to have you return to your normal duties. What do you do?

$\square$ Nothing, go back to your normal duties as instructed.

$\square$ Speak to your boss and ask for further clarification about the situation

Speak to your boss and tell him/her that you are uncomfortable doing this

$\square$ Speak to the company's Chief Ethics Officer.

$\square$ Other (please explain):

\section{Scenario V:}

You are beginning a new semester at your college/university. Your financial aid has not arrived on time and if you do not pay your tuition, you will have to drop out. Although you do not live at home, you call your parents and ask to borrow some money. They are pretty broke right now but they reluctantly agree and send you the money needed and you pay your bill.

The financial aid arrives and you now have more money than expected. Your parents did not know that you would be getting financial aid. What do you do?

$\square$ Pay your parents back

Keep all the money and not tell your parents

$\square$ Pay off your credit cards with the money

$\square$ Pay some of the money back to your parents

$\square$ Other (please explain):

\section{Scenario VI:}

Someone you supervised was putting hours on his timecard that he was not working. S/He was a very good employee and always completed projects under budget. All of the hours were billed directly to a client, and they were happy with the costs they were incurring to have the work done. What do you do?

$\square$ Confront the employee 


\section{Scenario VII:}

As a sales representative, you often have to balance your personal gain with the customer's gain. You are compensated for a sale even if you believe that the customer should not purchase the product.

At the same time, if you did not produce your quota, your job would be in jeopardy.

A customer approaches you with a purchase of an exceedingly expensive watch. With this purchase you will receive a huge commission. Based upon their credit situation, paying for the watch through various credit cards, you deduce this may not be the best watch for them. What do you do?

$\square$ Let them purchase the watch anyway.

Refuse to sell them the watch

Try and steer them towards other less expensive watches

$\square$ Other (please explain):

\section{Scenario VIII:}

While you were employed as a production supervisor, you occasionally went out with the group for drinks. One subordinate, whom you found attractive, let it be known that s/he would like to date you. The company has no policy on work relationships. What do you do?

$\square$ Ask the person out on a date

$\square$ Tell the person that it would be inappropriate to mix business and pleasure

Ignore the person's comments

Other (please explain):

\section{Scenario IX:}

You work in a retail establishment and see your supervisor taking home merchandize at least once a week. Your uncle got you this job and is a good friend with the owner of the store.

What do you do?

$\square$ Nothing

Contact your uncle

Start taking merchandise too!

Other (please explain):

Scenario X:

While auditing one of your client's accounts, you came across something in the contract that had been overlooked by everyone involved. This item wasn't very large, just a few dollars here and there.

However, the contract was from a few years ago, and your client was very large, so the dollars added up.

The client was overcharged significantly. To correct this error, a credit would have to be applied to every single error, which would be extremely time-consuming for you and the client. You are short on staff and in the middle of your busiest season. You were the only one who recognized the error. What do you do? 
FIGURE 3

SCENARIO I PERCENTAGE OF RESPONDENTS BY YEAR



FIGURE 4

SCENARIO II PERCENTAGE OF RESPONDENTS BY YEAR

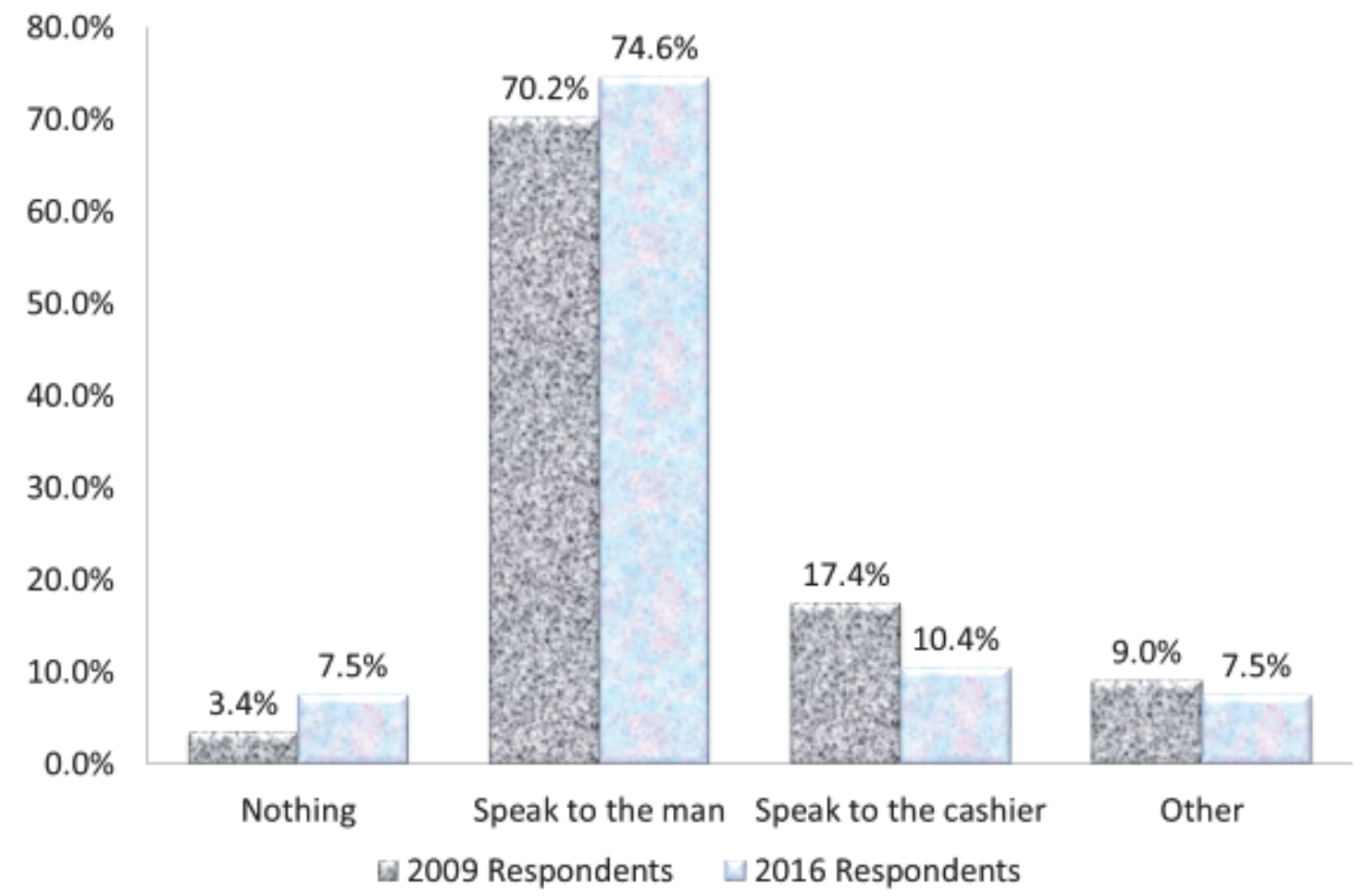

42 Journal of Leadership, Accountability and Ethics Vol. 16(2) 2019 
FIGURE 5

SCENARIO III PERCENTAGE OF RESPONDENTS BY YEAR
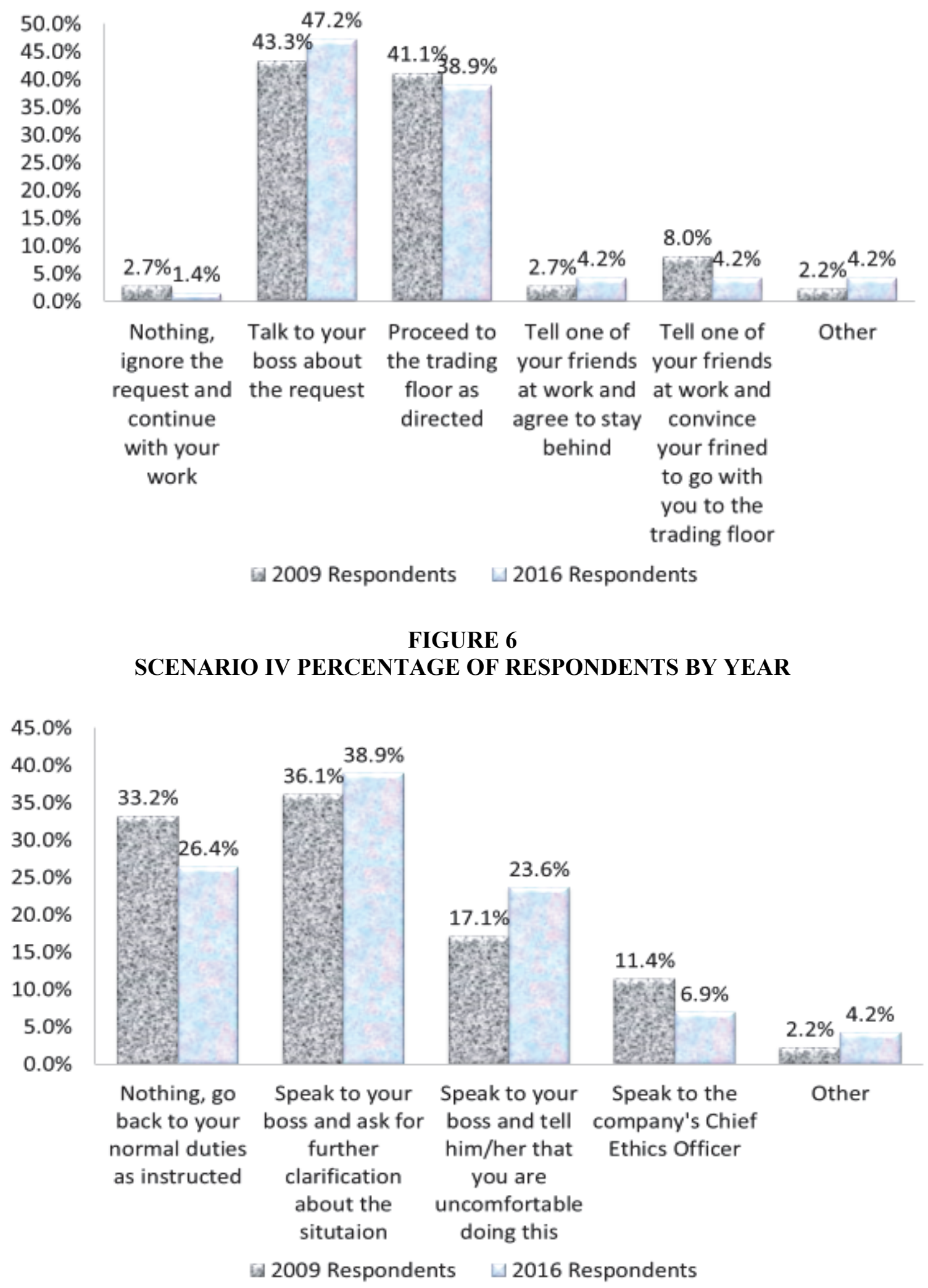
FIGURE 7

SCENARIO V PERCENTAGE OF RESPONDENTS BY YEAR

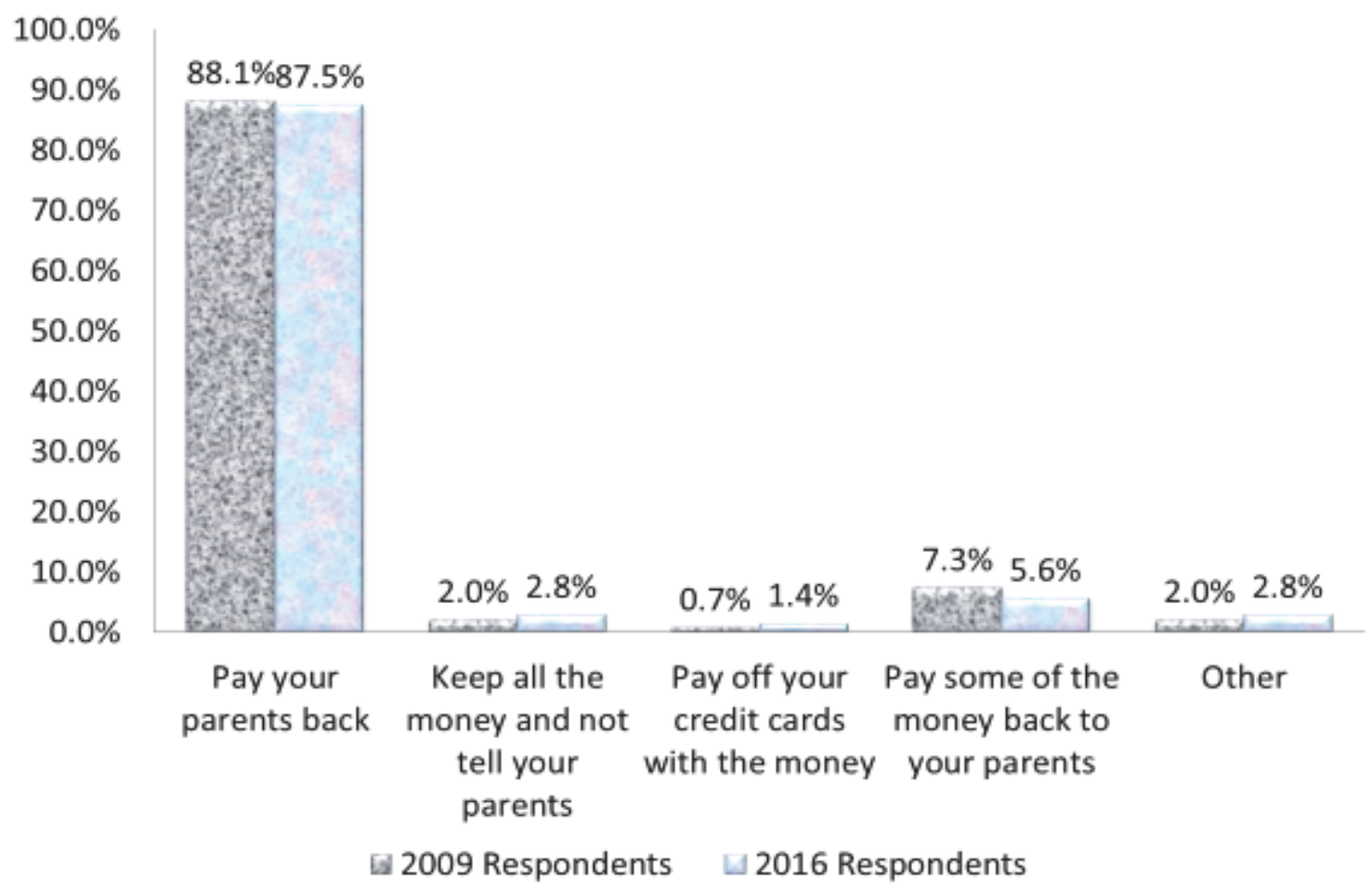

FIGURE 8

SCENARIO VI PERCENTAGE OF RESPONDENTS BY YEAR

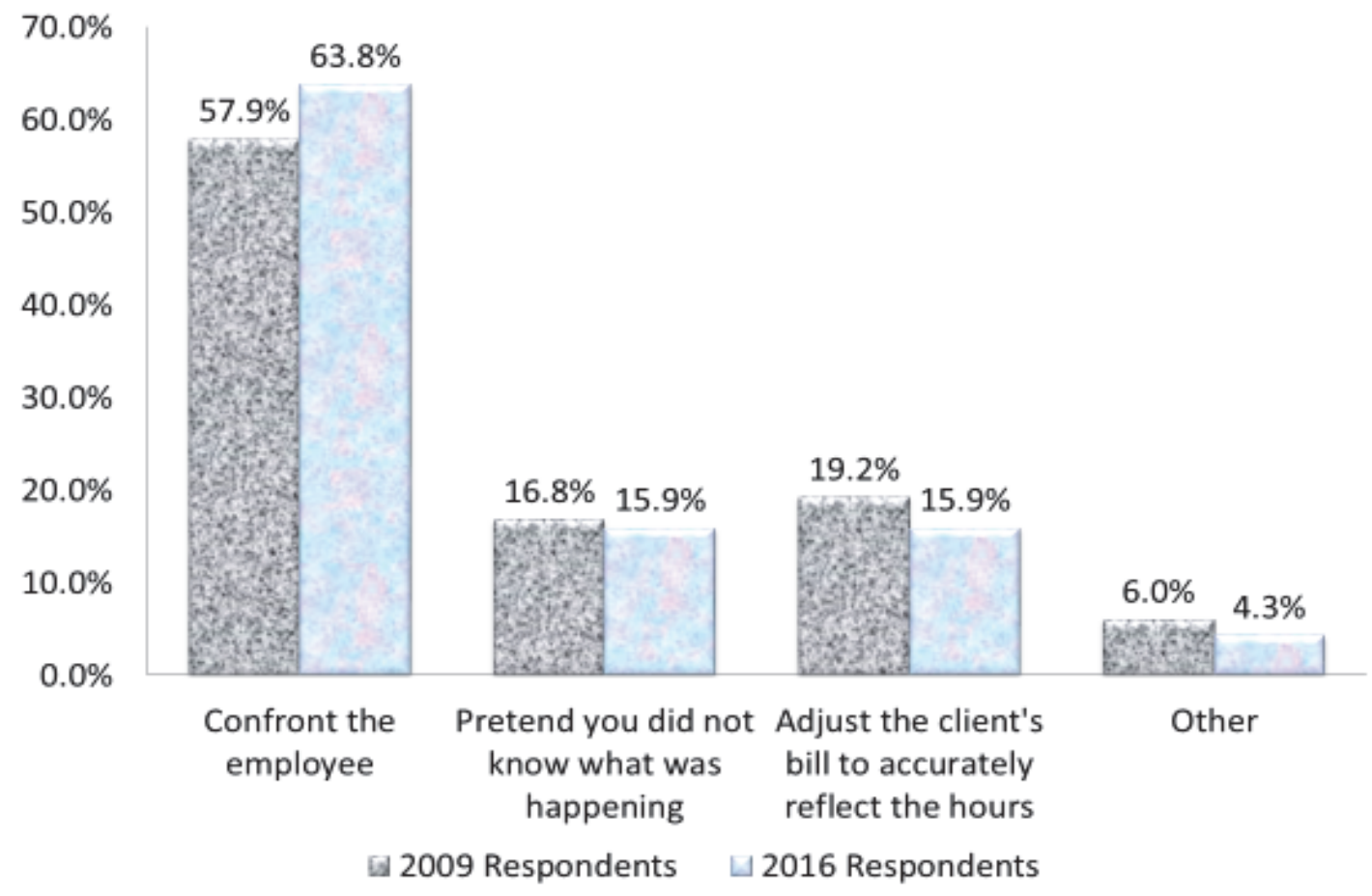

44 Journal of Leadership, Accountability and Ethics Vol. 16(2) 2019 
FIGURE 9

SCENARIO VII PERCENTAGE OF RESPONDENTS BY YEAR

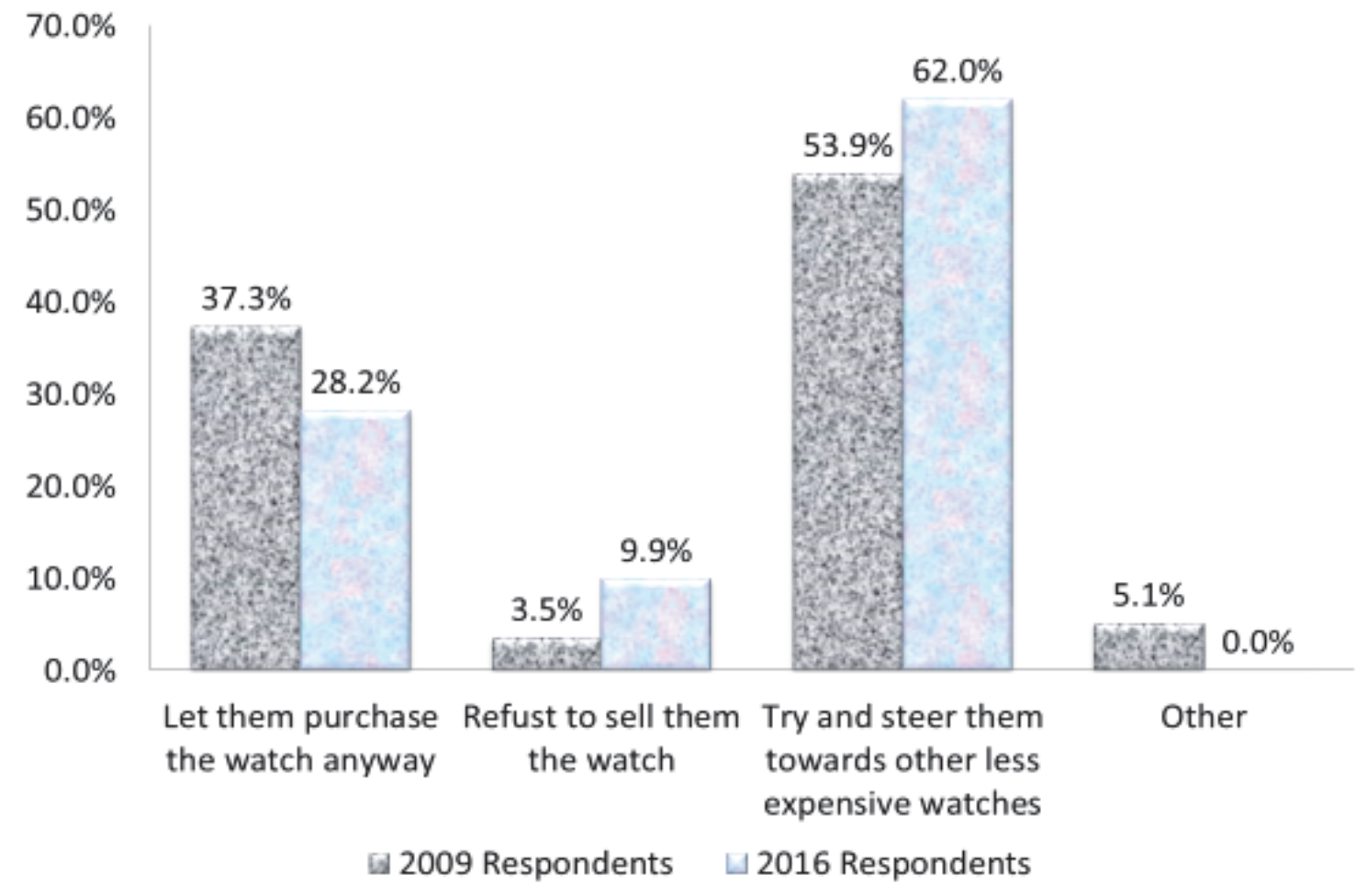

FIGURE 10

SCENARIO VIII PERCENTAGE OF RESPONDENTS BY YEAR*




FIGURE 11

SCENARIO IX PERCENTAGE OF RESPONDENTS BY YEAR

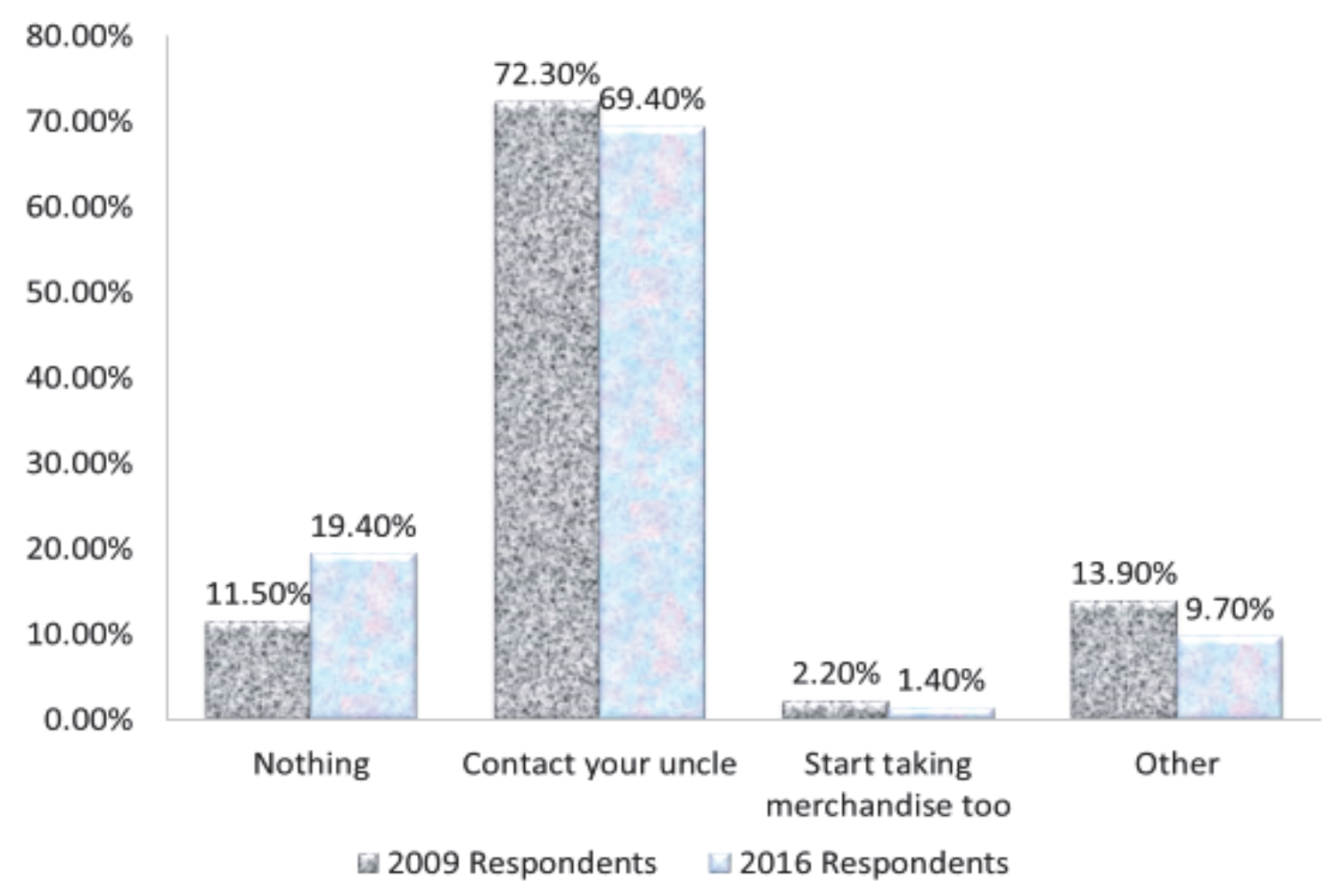

FIGURE 12

SCENARIO X PERCENTAGE OF RESPONDENTS BY YEAR



